\title{
PENGARUH MEDIA AUDIO VISUAL TERHADAP HASIL BELAJAR KRIYA KERAMIK DI SMK NEGERI 8 PADANG
}

\author{
Bella Eka Pratiwi \\ Program Studi Pengkajian Kriya \\ Program Pascasarjana Institut Seni Indonesia, Yogyakarta, Indonesia \\ e-mail : bellaeka955@gmail.com \\ Diterima : 10 Maret 202ㅁ. Disetujui : $2 \underline{3}$ Maret 2020. Dipublikasikan : 10 Juni 2020 \\ (O)2020 - DESKOVI Universitas Maarif Hasyim Latif. Ini adalah artikel dengan akses \\ terbuka di bawah lisensi CC BY 4.0 (https://creativecommons.org/licenses/by/4.0/)
}

\begin{abstract}
ABSTRAK
Penelitian ini bertujuan untuk mengetahui pengaruh media audio visual terhadap hasil belajar kriya keramik di SMK Negeri 8 Padang. Hipotesis yang diuji dalam penelitaian ini adalah hasil belajar kriya keramik yang diajar dengan menggunakan media audio visual berbeda secara signifikan dengan hasil belajar kriya keramik yang diajar dengan menggunakan media konvensional. Populasi dalam penelitian ini adalah seluruh siswa kriya keramik. Sampel pada penelitian ini adalah siswa kelas XI kriya keramik. Teknik pengambilan sampelnya adalah purposive sampling. Jenis penelitian yang digunakan adalah eksperimen semu (Quasi-experimen) dengan rancangan penelitian Pretest-Posttest Control Group Design. Data penelitian dikumpulkan dengan tes hasil belajar. Data kemudian dianalisis dengan Uji-t. Temuan penelitian menunjukkan bahwa: hasil belajar kriya keramik yang diajarkan dengan menggunakan media audio visual berbeda dengan hasil belajar kriya keramik yang diajar dengan menggunakan media konvensional. Berdasarkan temuan penelitian di atas, dapat disimpulkan bahwa media audio visual berpengaruh positif terhadap hasil belajar siswa dalam mata pelajaran kriya keramik. Oleh karena itu media audio visual sangat baik untuk digunakan secara terus menerus oleh guru dalam proses pembelajaran guna untuk meningkatkan hasil belajar siswa khususnya pada mata pelajaran kriya keramik di SMK Negeri 8 Padang.
\end{abstract}

Kata kunci: Media Audio Visual, Hasil Belajar Siswa.

\begin{abstract}
This research aims to understand the influence of audio visual media to the result of learning pottery crafting in SMK Negeri 8 Padang. This research tested the hypothesis to know is there a significant difference in the result of learning pottery crafting taught by using audio visual media and conventional media. The population is all of the pottery crafting students. The sample is the students of class XI pottery crafting. The technique of sampling is purposive sampling. The type of research is quasi experiment with research plan is Pretest-Posttest Control Group Design. The data is collected by testing the learning result. Then, data will be analyzed by using Uji-t. The result shows : the learning result of pottery crafting that has been taught using audio visual media is difference with the result of learning by using conventional media. Based on the result of the research, we can conclude that audio visual media has positive influence towards students's learning result in pottery crafting subject. Therefore, the audio visual media is really good to use continuosly by the teacher in the learning process in order to improve the students's learning result specifically in pottery crafting subject in SMK Negeri 8 padang.
\end{abstract}

Keyword: audio visual media, students's learning result.

\section{PENDAHULUAN}

Pendidikan merupakan sumber daya manusia yang sepatutnya mendapat perhatian terus menerus dalam upaya meningkatkan mutunya. Peningkatan mutu pendidikan berarti pula meningkatkan kualitas sumber daya manusia. Untuk itu dilakukan pembaharuan dalam bidang pindidikan dari waktu ke waktu secara continue. Keberhasilan dunia pendidikan terutama tergantung pada sejauh mana kita mengembangkan keterampilan-keterampilan yang tepat untuk menguasai kompleksitas dan ketidakpastian yang saling berhubungan satu dengan yang lainnya.

Sarana berupa laptop, LCD, proyektor, dan komputer, tersedia di sekolah ataupun dimiliki oleh guru. Seharusnya ketersediaan sarana penunjang pembelajaran tersebut berkonsekuensi hasil belajar siswa menjadi lebih baik. Tetapi kenyataannya hasil belajar siswa khususnya pembelajaran kriya keramik masih rendah atau di bawah KKM yaitu 75. Sementara tujuan pembelajaran dari kriya keramik yaitu agar siswa mampu mengembangkan proses dalam 
pembentukan kriya keramik, menguasai berbagai teknik yang ada. (Sumber berdasarkan dari tujuan pembelajaran kriya keramik) di SMK Negeri 8 Padang.

Salah satu usaha dari berbagai alternatif yang dapat dilakukan guru untuk meningkatkan hasil belajar siswa pada pembelajaran kriya keramik adalah dengan menggunakan media pembelajaran audio visual, media audio visual ini menarik dan sesuai dengan materi yang diajarkan, agar siswa terlibat untuk belajar lebih aktif, dan kreatif di dalam proses pembelajaran, dengan adanya media audio visual siswa lebih jelas bagaimana cara melakukan suatu pekerjaan praktek dengan mudah dan cepat dipahami, sehingga kompetensi dan kreativitas setiap siswa bisa berkembang.

Menurut Jufri (2013: 38) hakekat belajar dan prinsip-prinsip pembelajaran "Belajar sering juga dimaknai sebagai adanya perolehan keterampilan dan ilmu pengetahuan. Seiring dengan perkembangan mutakhir yang didukung oleh hasil kajian neurofisiologi dan neuropsikologi makna belajar menjadi lebih luas yakni melibatkan kemampuan memproses informasi, menalar, dan mengembangkan pemahaman serta meningkatkan penguasaan keterampilan dalam proses pembelajaran".

Skinner (1958) dalam Mulyadi (2016: 35) memberikan definisi belajar sebagai "a process of progressive behavior adaption". Jadi belajar merupakan suatu proses adaptasi (penyesuain) perilaku yang bersifat progresif. Ini berarti akibat dari belajar terjadi perilaku adaptasi yang bersifat progresif, perilaku adaptasi yang cenderung ke arah yang lebih baik.

Pengertian media pembelajaran menurut Gerlach \& Ely (1971) dalam Arsyad (2015 : 3) bahwa "media apabila dipahami secara garis besar adalah manusia, materi, atau kejadian yang membangun kondisi yang membuat siswa mampu memperoleh pengetahuan, keterampilan, atau sikap".

Sering kali kata media pendidikan digunakan secara bergantian dengan istilah alat bantu atau media komunikasi seperti yang dikemukakan oleh Hamalik (1986) dalam Arsyad (2015 : 4) dimana ia melihat bahwa "hubungan komunikasi akan berjalan lancar dengan hasil yang maksimal apabila menggunakan alat bantu yang disebut media komunikasi."

Dalam proses pembelajaran, media memiliki fungsi sebagai pembawa informasi dari sumber (guru/pendidik) menuju penerima (siswa/peserta didik). Sedangkan metode adalah prosedur untuk membantu peserta didik dalam menerima dan mengelola informasi guna mencapai tujuan pembelajaran (Daryanto 2016:8). Menurut Anderson (1994) dalam Waryanto (2007: 1) "media video adalah merupakan rangkaian gambar elektronis yang disertai oleh unsur suara audio juga mempunyai unsur gambar yang dituangkan melalui pita video (video tape)". Rangkaian gambar elektronis tersebut kemudian diputar dengan suatu alat yaitu video cassette recorder atau video player.

Menurut Wati (2016: 43) pengertian audio visual:“Audio visual merupakan salah satu media yang menampilkan unsur suara dan unsur gambar. Penggabungan kedua unsur inilah yang membuat media audio visual memiliki kemampuan yang lebih baik. Audio visual merupakan media yang terdiri atas media auditif atau mendengar dan visual atau melihat. Media audio visual merupakan sebuah alat bantu yang dipergunakan dalam pembelajaran untuk membantu tulisam dan kata yang diucapkan dalam menyampaikan pengetahuan, sikap, dan ide dalam materi pembelajaran".

Media pembelajaran yang berbasis audio visual merupakan penyampaian pesan pembelajaran yang mengandung unsur visual dan suara. Karena menggunakan lebih dari satu indera dalam pemanfaatannya, maka media audio visual ini sering kali juga dimasukkan dalam kelompok multimedia. Dalam konteks komunikasi, media audio visual memiliki fungsi edukatif, fungsi sosial, fungsi ekonomis, dan fungsi budaya (Wati, 2016: 51-54).

Media pembelajaran audio visual memiliki langkah-langkah dalam penggunaannya seperti halnya media pembelajaran lainnya. Langkah-langkah pembelajaran menggunakan media audio visual adalah sebagai berikut.

\section{Persiapan}

Kegiatan yang dilakukan oleh guru pada saat persiapan yaitu buku petunjuk penggunaan media, peralatan media yang akan digunakan.

\section{Pelaksanaan/Penyajian}

Pada saat melaksanakan pembelajaran menggunakan media audio visual, guru perlu mempertimbangkan seperti memastikan media dan semua peralatan telah lengkap dan siap digunakan, menjelaskan materi pelajaran kepada siswa selama proses pembelajaran berlangsung, dapat mengganggu konsentrasi siswa.

\section{Tindak lanjut}

Aktivitas ini dilakukan untuk memantapkan pemahaman siswa tentang materi yang telah disampaikan menggunakan media audio visual. Di samping itu aktivitas ini bertujuan untuk mengukur efektivitas pembelajaran yang telah dilaksanakan. Kegiatan yang bisa dilakukan di antaranya diskusi, observasi, eksperimen, latihan dan tes adaptasi dari Sumarno (2011, Blog.elearning-unesa.ac.id).

\section{METODE PENELITIAN}

Jenis penelitian yang digunakan adalah eksperimen, yaitu penelitian untuk melihat dan meneliti adanya akibat setelah subjek dikenai perlakuan pada variabel bebasnya. Jadi penelitian eksperimen ini adalah penelitian yang bertujuan untuk melihat hubungan sebab akibat tersebut adalah dengan membandingkan satu kelompok eksperimen yang diberi perlakuan dengan kelompok pembanding yang tidak diberi perlakuan. Bentuk eksperimen yang digunakan adalah eksperimen semu (Quasiexperimen), dengan rancangan penelitian PretestPosttest Control Group Design. 
Sugiyono (2014: 80) memberikan definisi bahwa populasi adalah wilayah generalisasi yang terdiri dari objek atau subjek yang menjadi kuantitas dan karakteristik tertentu, ditetapkan oleh peneliti untuk dipelajari dan kemudian di tarik kesimpulan.

Populasi dalam penelitian ini adalah semua siswa jurusan kriya keramik SMK Negeri 8 Padang.

Penelitian ini terdiri dari dua variabel bebas yang dimanipulasi, yaitu media audio visual dan media konvensional. Sedangkan yang menjadi variabel terikatnya adalah hasil belajar siswa dalam mata pelajaran kriya keramik.

Dalam penelitian ini teknik pengumpulan data dengan cara memberikan test pada kedua kelas yaitu kelas eksperimen dan kelas kontrol. Tes yang diberikan berupa tes perbuatan (praktik).

\section{HASIL DAN PEMBAHASAN}

\section{Hasil Tes Pengetahuan Awal (Pretest)}

Hasil tes pengetahuan awal (pretest) ini peneliti menggunakan materi membentuk keramik dengan teknik putar pada kelompok eksperimen dan kelompok kontrol dapat diketahui dari nilai tes siswa. Adapun deskripsi hasil tes pengetahuan awal siswa (pretest) pada kedua kelompok siswa dapat dilihat pada tabel berikut :

\begin{tabular}{|c|c|c|c|c|c|}
\hline \multirow[t]{2}{*}{$\begin{array}{l}\mathbf{N} \\
\mathbf{0}\end{array}$} & \multirow[t]{2}{*}{$\begin{array}{c}\text { Skor } \\
\text { Pretest }\end{array}$} & \multicolumn{2}{|c|}{$\begin{array}{c}\text { Kelas } \\
\text { Ekperimen }\end{array}$} & \multicolumn{2}{|c|}{ Kelas Kontrol } \\
\hline & & $\mathbf{F}$ & $\%$ & $\mathbf{F}$ & $\%$ \\
\hline 1 & 60 & - & - & 1 & 5.6 \\
\hline 2 & 65 & 1 & 5.9 & 1 & 5.6 \\
\hline 3 & 68 & 1 & 5.9 & - & - \\
\hline 4 & 70 & 3 & 17.6 & 4 & 22.2 \\
\hline 5 & 72 & 4 & 23.5 & - & - \\
\hline 6 & 73 & 1 & 5.9 & - & - \\
\hline 7 & 75 & 5 & 29.4 & 7 & 38.9 \\
\hline 8 & 77 & 2 & 11.8 & 2 & 11.1 \\
\hline 9 & 78 & - & - & 3 & 16.7 \\
\hline \multicolumn{2}{|c|}{ Jumlah } & 17 & 100.0 & 18 & 100.0 \\
\hline \multicolumn{2}{|c|}{ Rata-Rata } & \multicolumn{2}{|c|}{72.53} & \multicolumn{2}{|c|}{73.22} \\
\hline
\end{tabular}

Sumber : Olah data SPSS V 16.0

Tabel 1. Distribusi Frekuensi Tes Pengetahuan Awal (Pretest) Kelas Eksperimen dan Kelas Kontrol

Hasil tabel distribusi tes pengetahuan awal (pretest) di atas dapat dilihat nilai rata-rata kelas eksperimen yaitu 72.53. skor tertinggi pada kelas eksperimen ini didapat dengan nilai 77 dengan jumlah 2 orang siswa dan jumlah presentase $11.8 \%$ sedangkan skor terendah pada tabel di atas yaitu 65 dengan jumlah 1 orang siswa dan jumlah presentase $5.9 \%$. sedangkan pada kelas kontrol dapat dilihat pada tabel di atas nilai rata-rata pada kelas kontrol ini yaitu 73.22. skor tertinggi yang diperoleh pada kelas kontrol ini yaitu 78 dengan jumlah 3 orang siswa dengan jumlah presentase $16.7 \%$ sedangkan skor terendah didapatkan dengan nilai 60 sebanyak 1 orang siswa dengan jumlah presentase $5.6 \%$.

Berdasarkan tabel distribusi frekuensi di atas dapat dilihat bahwa nilai pretest sebelum diberi perlakuan nilai siswa masih jauh dari batas KKM yang telah ditentukan pada kelas eksperimen dan kelas kontrol. KKM yang ditentukan dari sekolah yaitu 75 . Nilai rata-rata eksperimen $72.53<$ dari KKM dan kelas kontrol nilai rata-rata $73.22<$ dari KKM.

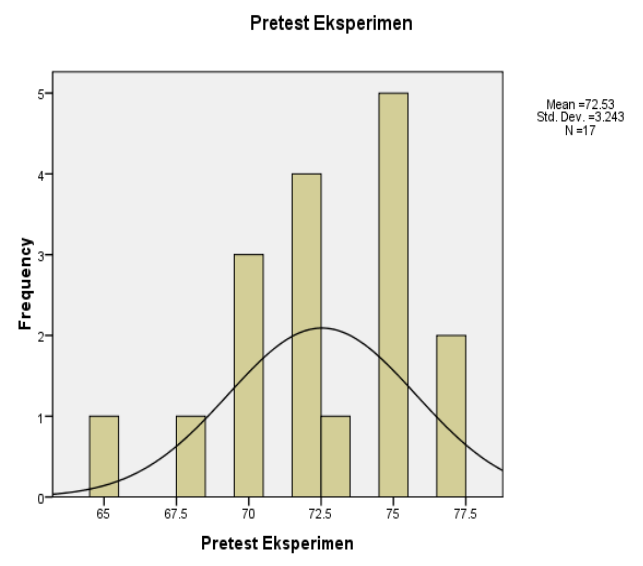

Gambar 1. Grafik Histrogram Distribusi Frekuensi Tes Pengetahuan Awal (Pretest) Kelas Eksperimen

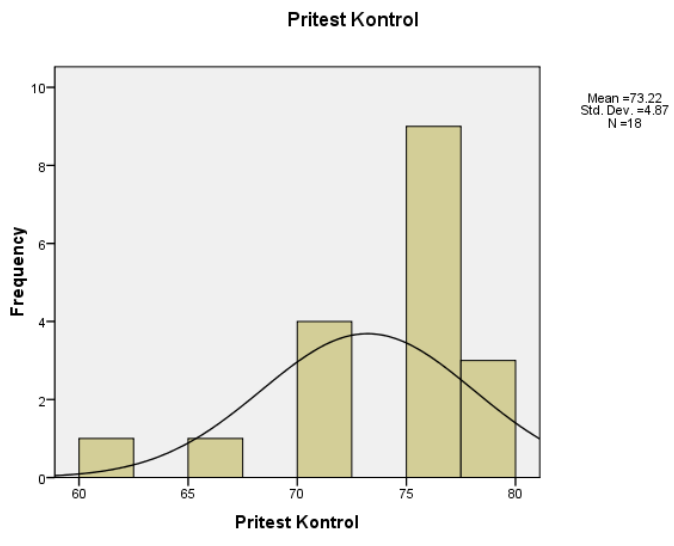

Gambar 2. Grafik Histrogram Distribusi Frekuensi Tes Pengetahuan Awal (Pretest) Kelas Kontrol

\section{Hasil Test Hasil Belajar (Posttest)}

Berdasarkan tes hasil belajar diperoleh setelah kedua kelas diberi perlakuan, baik itu kelas eksperimen maupun kelas kontrol. Kelas eksperimen pada proses pembelajarannya diberi perlakuan dengan menggunakan media audio visual, sedangkan kelas kontrol proses pembelajarannya menggunakan media 
konvensional. Tes hasil belajar ini diberikan pada pertemuan terakhir yakni

pada pertemuan ketiga yang diberikan kepada kedua kelas yaitu eksperimen dan kelas kontrol. Untuk hasil tes belajar (posstest) dari kedua kelas dapat dilihat pada tabel berikut :.

\begin{tabular}{|c|c|c|c|c|c|}
\hline \multirow[t]{2}{*}{ No } & \multirow[t]{2}{*}{$\begin{array}{l}\text { Skor } \\
\text { Pretest }\end{array}$} & \multicolumn{2}{|c|}{$\begin{array}{c}\text { Kelas } \\
\text { Ekperimen }\end{array}$} & \multicolumn{2}{|c|}{$\begin{array}{c}\text { Kelas } \\
\text { Kontrol }\end{array}$} \\
\hline & & $\mathbf{F}$ & $\%$ & $\mathbf{F}$ & $\%$ \\
\hline 1 & 60 & - & - & 1 & 5.6 \\
\hline 2 & 65 & - & - & 1 & 5.6 \\
\hline 3 & 70 & - & - & 4 & 22.2 \\
\hline 4 & 75 & - & - & 2 & 11.1 \\
\hline 5 & 78 & - & - & 3 & 16.7 \\
\hline 6 & 80 & 3 & 17.6 & 3 & 16.7 \\
\hline 7 & 83 & - & - & 1 & 5.6 \\
\hline 8 & 85 & 6 & 35.3 & 3 & 16.7 \\
\hline 9 & 88 & 3 & 17.6 & - & - \\
\hline 10 & 90 & 3 & 17.6 & - & - \\
\hline 11 & 95 & 2 & 11.8 & - & - \\
\hline \multicolumn{2}{|c|}{ Jumlah } & 17 & 100.0 & 18 & 100.0 \\
\hline \multicolumn{2}{|c|}{ Rata-Rata } & \multicolumn{2}{|c|}{86.71} & \multicolumn{2}{|c|}{75.94} \\
\hline
\end{tabular}

Sumber : Olah data SPSS V 16.0

Tabel 2. Distribusi Frekuensi Tes Hasil Belajar (Posttest) Kelas Eksperimen dan Kelas Kontrol

Berdasarkan pada tabel distribusi frekuensi tes hasil belajar (posttest) di atas dapat dilihat nilai ratarata kelas eksperimen yaitu 86.71. sedangkan nilai tertinggi pada kelas eksperimen ini yaitu 95 dengan jumlah 2 orang siswa dengan jumlah presentase $11.8 \%$ dan nilai terendah pada kelas eksperimen ini adalah 80 dengan jumlah 3 orang siswa dengan jumlah prentase $17.6 \%$. untuk kelas kontrol sendiri dapat dilihat pada tabel dengan nilai rata-rata 75.94. skor tertinggi pada kelas kontrol ini yaitu didapat dengan nilai 85 dengan jumalh 3 orang siswa dan jumlah presentase $16.7 \%$. sedangkan untuk nilai terendahnya yaitu didapatkan 60 dengan 1 orang siswa dengan jumlah presentase 5.6\%.

Berdasarkan tabel distribusi frekuensi di atas dapat dilihat bahwa nilai posttest tes setelah diberi perlakuan nilai siswa pada kelas eksperimen dengan diberi perlakuan menggunakan media audio visual sudah mencapai dari batas KKM yaitu 75, sedangkan pada kelas kontro di beri perlakuan dengan menggunakan media konvensional nilai rata-rata yang didapat sangat minimum yaitu 75 . Nilai rata-rata kelas eksperimen yaitu 86.71 > dari KKM yaitu 75 dan pada kelas kontrol yaitu $75.94>$ dari KKM yaitu 75 . Berdasarkan pada distribusi frekuensi hasil belajar (posttest) dapat dilihat distribusi grafik histrogram sebagai berikut :

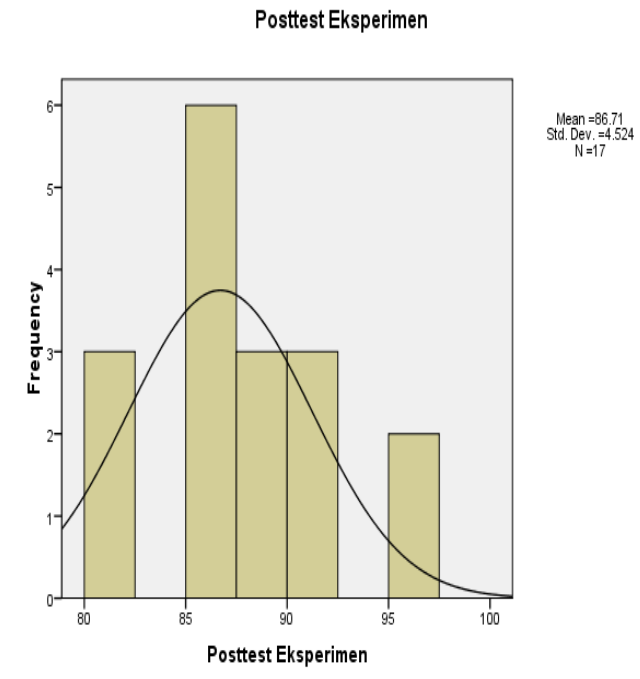

Gambar 3. Grafik Histrogram Distribusi Frekuensi Tes Hasil Belajar (Posstest) Kelas Eksperimen

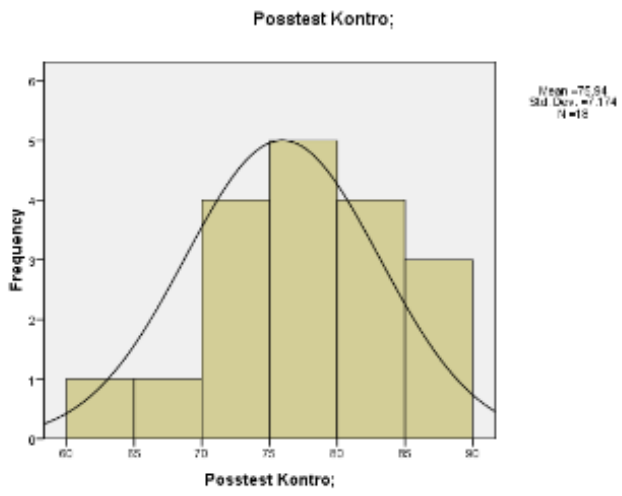

Gambar 4. Grafik Histrogram Distribusi Frekuensi Tes Hasil Belajar (Posttest) Kelas Kontrol

\section{Pengujian Persyaratan Analisis}

Untuk menarik kesimpulan dari hasil penelitian maka penulis melakukan pengujian hipotesis secara statistik. Sebelum melakukan pengujian hipotesis terlebih dahulu peneliti melakukan uji normalitas dan uji homogenitas.

a. Uji Normalitas

Pengujian normalitas data dilakukan setelah pendistribusian dan pengelompokkan data dengan menggunakan bantuan software program SPSS versi 16.00 for window. Tujuan dari uji normalitas ini adalah untuk menguji apakah data terdistribusi secara normal atau tidak. Pengujian normalitas dalam penelitian ini dilakukan dengan menggunakan one sample Kolmogorov-Smirnov test. Berdasarkan uji normalitas data hasil belajar dan pengetahuan awal siswa kelas eksperimen dan kelas kontrol ditunjukkan pada table 7 berikut ini: 
One-Sample Kolmogorov-Smirnov Test

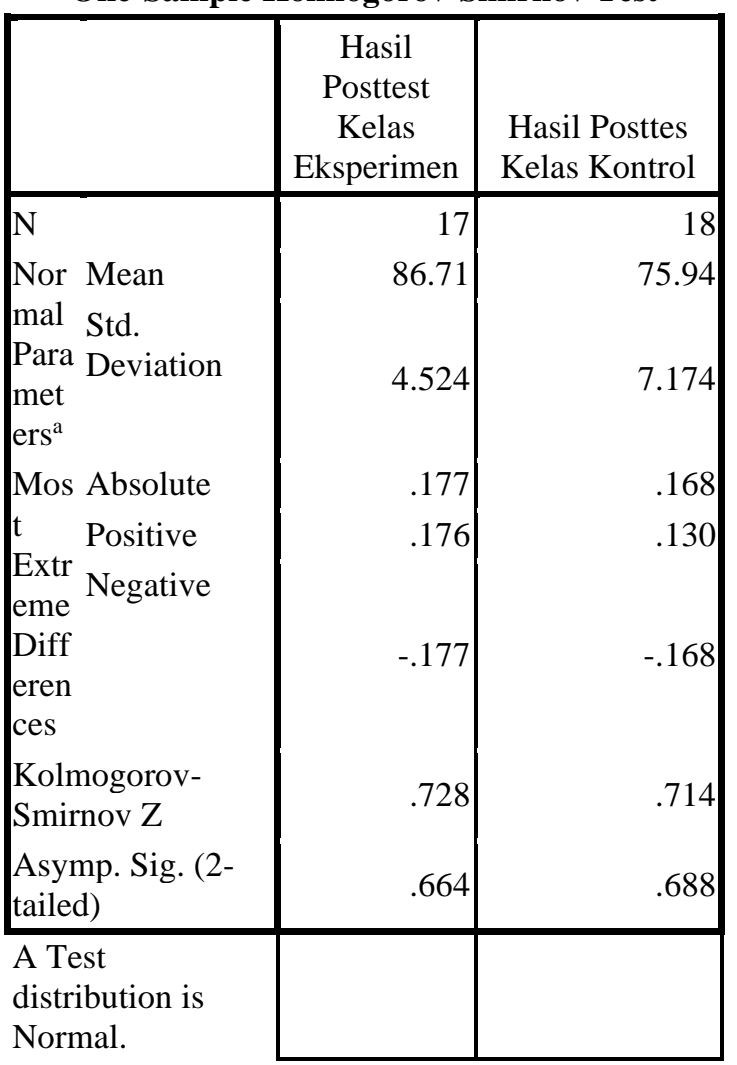

.Tabel 3. Hasil Uji Normalitas Data Tes Pengetahuan Awal (Pretest) Kelas Eksperimen dan Kelas Kontrol

\section{One-Sample Kolmogorov-Smirnov Test}

\begin{tabular}{|c|c|c|}
\hline & $\begin{array}{l}\text { Hasil Pretest } \\
\text { Kelas } \\
\text { Eksperimen }\end{array}$ & $\begin{array}{l}\text { Hasil Pretest } \\
\text { Kelas Kontrol }\end{array}$ \\
\hline $\mathrm{N}$ & 17 & 18 \\
\hline Normal Mean & 72.53 & 73.22 \\
\hline $\begin{array}{ll}\text { Paramete } & \text { Std. } \\
\mathrm{rs}^{\mathrm{a}} & \text { Deviation }\end{array}$ & 3.243 & 4.870 \\
\hline Most $\quad$ Absolute & .189 & .309 \\
\hline Extreme Positive & .105 & .163 \\
\hline $\begin{array}{ll}\text { Differenc } & \\
\text { es } & \text { Negative }\end{array}$ & -.189 & -.309 \\
\hline $\begin{array}{l}\text { Kolmogorov- } \\
\text { Smirnov Z }\end{array}$ & .778 & 1.312 \\
\hline $\begin{array}{l}\text { Asymp. Sig. (2- } \\
\text { tailed) }\end{array}$ & .580 & .064 \\
\hline $\begin{array}{l}\text { A Test distribution } \\
\text { is Normal. }\end{array}$ & & \\
\hline
\end{tabular}

Tabel 4. Hasil Uji Normalitas Data Hasil Belajar (Posttest) Kelas Eksperimen dan Kelas Kontrol

\section{b. Uji Homogenitas}

Setelah dilakukan uji normalitas selanjutnya dilakukan uji homogenitas. Uji homogenitas bertujuan untuk melihat apakah kedua kelompok data memiliki varians yang homogen atau tidak. Pengujian homogenitas menggunakan metode homogenitas varience. Berdasarkan uji homogenitas data hasil belajar dan pengetahuan awal siswa diperoleh hasil seperti Tabel di bawah.

\section{Test of Homogeneity of Variances}

Hasil Pretest

\begin{tabular}{|c|c|c|c|}
$\begin{array}{c}\text { Levene } \\
\text { Statistic }\end{array}$ & df1 & df2 & Sig. \\
\hline 2.293 & 1 & 33 & .139 \\
\hline
\end{tabular}

Hasil

Posttest

\begin{tabular}{|r|r|r|rr|}
\hline $\begin{array}{r}\text { Levene } \\
\text { Statistic }\end{array}$ & df1 & df2 & \multicolumn{2}{|c|}{ Sig. } \\
\hline 3.993 & 1 & 33 & & .054 \\
\hline
\end{tabular}

Sumber: Olah data SPSS Versi 16.0

Tabel 6. Hasil uji Homogenitas Tes Hasil Belajar (Posttest) Kelas Eksperimen dan Kelas Kontrol

\section{c. Uji Hipotesis}

Uji hipotesisi dilakukan setelah uji normalitas dan uji homogenesis pada kelas eksperimen dan kelas kontrol, dari perhitungan diketahui data berdistribusi normal dan sampel mempunyai varians yang homogen. Sedangkan untuk menguji hipotesis ini dilakukan dengan menggunakan uji t Independent Sampel T Test. Data yang digunakan pada uji hipotesis ini adalah menggunakan dua nilai selisi skor pretest dan posttest dari kelas eksperimen dan kelas kontrol. Pada Uji-t Independent sampel t Test ini menggunakan data SPSS Versi 16.0.

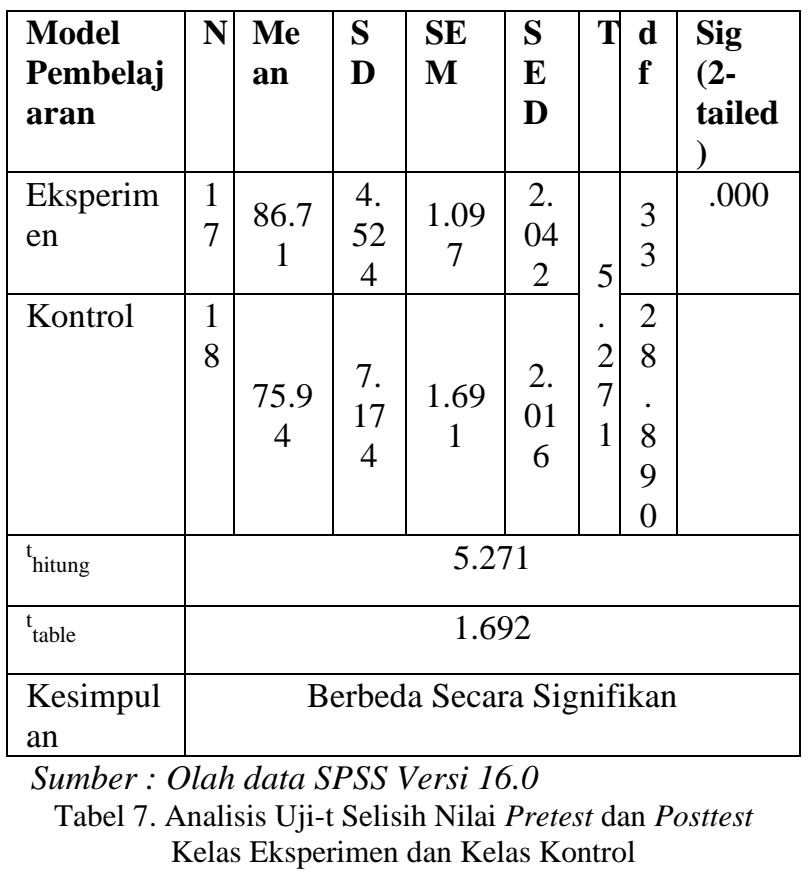

\section{KESIMPULAN}


Berdasarkan permasalahan penelitian ini, maka peneliti dapat mengambil kesimpulan sebagai berikut:

Pada hasil belajar terdapat nilai dari rata-rata kelas eksperimen yang menggunakan media pembelajaran audio visual adalah 86,71 lebih tinggi dibandingkan dengan menggunakan media pembelajaran konvensional pada kelas kontrol yaitu 75,94 .

Berdasarkan pada hasil belajar dalam pembelajaran kriya keramik yang diajar dengan menggunakan media pembelajaran audio visual ini berbeda secara signifikan dengan hasil belajar siswa dalam pembelajaran kriya keramik yang diajar berdasarkan media pembelajaran konvensional di kelas XI SMK Negeri 8 Padang. Adapun pada uji hipotesis terdapat hasil belajar kelas eksperimen dan kelas kontrol, diketahui dengan perhitungannya thitung $=$ 5,271 dan ttable $=1,692$. Hal ini menunjukkan bahwa thitung > ttable, dapat peneliti simpulkan bahwa Ho ditolak. Untuk itu dapat disimpulkan bahwa penggunaan dari media pembelajaran audio visual dapat berpengaruh positif pada hasil belajar siswa dalam pembelajaran kriya keramik di SMK Negeri 8 Padang.

Berdasarkan kesimpulan yang peneliti peroleh bahwasannya untuk meningkatkan hasil belajar siswa pada kriya keramik di SMK Negeri 8 Padang. Untuk itu peneliti ingin menyarankan beberapa hal yaitu :1) Bagi Peneliti Setelah selesainnya penelitian ini diharapkan peneliti mampu mengembangkan kembali media audio visual saat mengajar nanti di sekolah. 2) Bagi Siswa diharapkan lebih semangat dan termotivasi dalam mengikuti pelajaran setelah diberi pengelaman belajar dengan menggunakan media audio visual. 3) Bagi Guru diharapkan mampu mengembangkan dan menggunakan media audio visual untuk kompetensi dasar lainnya. 4) Bagi Kepala Sekolah SMK Negeri 8 Padang hendaknya bisa mensosialisasikan media pembelajaran audio visual ini kedalam pembelajaran dan dapat memberikan suatu dukungan kepada guru untuk melaksanakannya dalam pembelajaran.

\section{DAFTAR PUSTAKA}

Arsyad, A. (2015). Media Pembelajaran. Jakarta: PT Rajagrafindo Persada.

Daryanto. (2016). Media Pembelajaran. Yogyakarta: Gava Media.

Ernawati, E. (2020). PSIKOLOGIS DALAM SENI: KATARSIS SEBAGAI REPRESENTASI DALAM KARYA SENI RUPA. DESKOVI: Art and Design Journal, 2(2), 105-112.

Jufri, W. (2013). Belajar dan Pembelajaran SAINS. Bandung: Penerbit Pustaka Reka Cipta.

Mulyadi, S. (2016). Psikologi Pendidikan. Jakarta: PT Raja Grafindo Persada.

Sugiyono. (2014). Metode Penelitian Kuantitatif, Kualitatif, dan R\&D. Bandung: CV Alfabeta.

Sumarno. (2011). Retrieved from blog.elearningunesa.ac.id.

Wati. (2016). Ragam Media Pembelajaran. Yogyakarta: Kata Pena. 